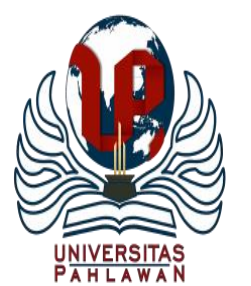

\author{
Jurnal Abdidas Volume 1 Nomor 5 Tahun 2020 Halaman 393 - 406 \\ JURNAL ABDIDAS \\ Community Development Service on Educational and Health Sciences \\ http://abdidas.org/index.php/abdidas
}

\title{
Strategi Pemasaran Produk Mudharabah di BMT Mitra Ummat Al-Amanah Kecamatan Sirampog, Brebes
}

\author{
Muhamad Syafiq Rofi \\ Pascasarjana IAIN Purwokerto \\ E-mail: muhamadsyafiqrofi@gmail.com
}

\begin{abstract}
Abstrak
Untuk bisa bertahan dan menarik nasabah harus menyiapkan strategi-strategi pemasaran produk yang disukai oleh anggota atau nasabah. Salah satunya BMT Mitra Ummat Al-Amanah. Dalam hal ini BMT Mitra Ummat Al-Amanah Kecamatan Sirampog Brebes harus memiliki strategi pemasaran produk mudharabah yang sesuai, sehingga dapat bertahan di dalam persaingan dengan lembaga keuangan lainnya yang ada di kecamatan Sirampog. Pokok masalah pada penelitian ini adalah bagaimana strategi pemasaran produk mudharabah yang digunakan oleh BMT Mitra Ummat Al-Amanah. Jenis penelitian ini adalah penelitian deskriptif-kualitatif. Dalam penelitian ini dimaksudkan untuk mengetahui strategi pemasaran produk mudharabah yang digunakan oleh BMT Mitra Ummat Al-Amanah Kecamatan Sirampog Brebes. Hasil penelitian menunjukan bahwa, BMT Mitra Ummat Al-Amanah Kecamatan Sirampog Brebes menjalankan strateginya terjun secara langsung ke masyarakat. Melakukan promosi dan melakukan jemput bola secara langsung ke tempat anggota atau nasabah, sehingga anggota atau nasabah memperoleh kemudahan dalam mengakses dan lebih dekat dengan BMT Mitra Ummat Al-Amanah.
\end{abstract}

Kata kunci: strategi pemasaran,mudharabah, BMT

Abstract

To be able to survive and attract customers must prepare product marketing strategies that are preferred by members or customers. One of them is BMT Mitra Ummat Al-Amanah. In this case BMT Mitra Ummat AlAmanah Sirampog Brebes District must have an appropriate marketing strategy for mudharabah products, so that they can survive in competition with other financial institutions in Sirampog sub-district. The main problem in this research is how is the marketing strategy of mudharabah products used by BMT Mitra Ummat Al-Amanah. This type of research is descriptive-qualitative research. This research is intended to determine the marketing strategy of mudharabah products used by BMT Mitra Ummat Al-Amanah District of Sirampog Brebes. The results showed that, BMT Mitra Ummat Al-Amanah District of Sirampog Brebes carried out its strategy to go directly to the community. Promoting and picking up the ball directly to the place of members or customers, so that members or customers get easy access and get closer to BMT Mitra Ummat Al-Amanah.

Keywords: Marketing Strategy, Mudharabah, BMT.

Copyright (c) 2020 Muhamad Syafiq Rofi

$\triangle$ Corresponding author

Address : IAIN Purwokerto

Email : muhamadsyafiqrofi@gmail.com

ISSN 2721- 9224 (Media Cetak)

Phone : 082323117771

ISSN 2721- 9216 (Media Online)

DOI : https://doi.org/10.31004/abdidas.v1i5.91 


\section{PENDAHULUAN}

Dalam era yang semakin modern banyak muncul dan berkembang lembaga keuangan baik lembaga keuangan konvensional maupun syariah. Perkembangan yang sangat signifikan membuat lembaga keuangan harus bisa bertahan dalam persaingan yang ketat untuk menarik nasabah baik kalangan bawah sampai kalangan atas. Cara berfikir manusia yang semakin maju dalam menyimpan uang atau meminjam uang tidak hanya dilakukan di bank saja, namun sekarang sudah merambah ke lembaga keuangan selain bank yang mereka kenal. Sama dengan dengan Baitul Maal Wa Tamwil termasuk di dalamnya.

Banyak lembaga keuangan makro maupun mikro yang tersebar sampai pelosok negeri belum mencapai suatu kondisi yang ideal jika diamati secara teliti. Hal ini terlihat jelas dari lembaga keungan yang hanya mengejar keuntungan, dan mengabaikan tujuan yang besar yaitu mengembangkan ekonomi masyarakat bawah. Lembaga keuangan baik makro maupun mikro mempunyai peran posisi yang sangat strategis dalam perkembangan ekonomi masyarat bawah. Dalam kondisi yang demikian inilah Baitul Maal Wa Tamwil muncul dan mencoba menawarkan solusi bagi masyarakat kelas bawah (Sumiyanto, 2008).

Baitul Maal Wa Tamwil atau biasa disingkat BMT adalah lembaga keuangan nonbank yang beroprasi berdasarkan syariat dengan prinsip bagi hasil, didirikan oleh dan untuk masyarakat di suatu tempat atau daerah. Baitul Maal Wa Tamwil memiliki dua bidang kerja yaitu sebagai lembaga mal (Baitul Mal) dan sebagai lembaga tamwil (Baitul Tamwil) (Azra, 2003).
Pada dasarnya Baitul Maal Wa Tamwil merupakan pengembangan dari konsep ekonomi Islam, terutama dalam bidang keuangan. Istilah Baitul Maal Wa Tamwil merupakan gabungan dari baitul mal dan baitul tamwil. Baitul mal yaitu lembaga keuangan yang kegiatannya mengelola dana yang bersifat nirlaba. Sedangkan baitul tamwil yaitu lembaga keuangan yang kegiatannya berorientasi pada ke profit atau keuntungan. Penghimpunan dana diperoleh dari simpanan dan penyalurannya dalam bentuk pembiayaan yang dijalankan berdasarkan prinsip-prinsip syariah. Kemudian keuntungan dibagi sesuai dengan kesepakatan yang telah disepakati sebelumnya.

Secara sederhana BMT atau Baitul Maal Wa Tamwil adalah balai usaha mandiri terpadu yang berintikan bayt al-mal wa al tamwil dengan kegiatan mengembangkan usaha-usaha proaktif dan investasi dalam kegiatan kualitas bagian ekonomi pengusaha kecil bawah dengan antara lain mendorong kegiatan menabung dan menunjang pembiayaan kegiatan ekonominya, selain itu Baitul Maal Wa Tamwil juga bisa menerima titipan zakat, infaq dan shadaqah serta menyalurkan sesuai dengan peraturan dan amanatnya (Janwari \& Djazuli, 2002).

Hadirnya Baitul Maal Wa Tamwil di tengahtengah masyarakat membawa angin segar, karena masyarakat akan lebih dekat dengan lembaga keuangan yang berprinsip syariah dan terhindar dari proses-proses riba dalam bertransaksi di lembaga keuangan. Selain itu masyarakat terhindar dari jeratan rentenir dengan menerapkan sistem bunga yang nantinya akan mencekik masyarakat yang meminjam dan menjadikan masyarakat itu sendiri semakin lemah dan tidak berdaya. Selain 
itu kehidupan masyarakat yang berkecukupan, muncul kekhawatiran akan lemahnya pemahaman ekonomi syariah. Lemahnya pemahaman ini bukan hanya dipengaruhi oleh kurangnya pemahaman Islam, tapi juga dipengaruhi oleh lemahnya syiarsyiar Islam di masyarakat. Oleh karena itu hadirnya Baitul Maal Wa Tamwil diharapkan mampu dan lebih aktif dalam memperbaiki pengetahuan ekonomi syariah di masyarakat.

Dengan pergerakan yang sangat cepat dan akurat ini serta dalam pengelolaan oleh tenaga muda yang progresif dan inovatif membuat Baitul Maal Wa Tamwil akan cepat dikenal oleh masyarakat luas dan mutu produk yang sesuai dengan kebutuhan anggotanya. Selain itu Baitul Maal Wa Tamwil juga dituntut untuk memberikan pelayanan yang terbaik untuk anggotanya dan harus mampu berhubungan baik dengan masyarakat sebagai anggotanya. Oleh karena itu Baitul Maal Wa Tamwil harus memberikan pelayanan dengan mutu terbaik, sebab tanpa adanya anggota, Baitul Maal Wa Tamwil tidak dapat beroperasi. Dengan demikian Baitul Maal Wa Tamwil yang notabene lembaga keuangan mikro cepat berkembang dan populer dikalangan masyarakat lapisan menengah ke bawah dengan berbagai produknya.

Ada beberapa jenis-jenis produk pembiayaan di Baitul Maal Wa Tamwil yaitu pembiayaan mudharabah, murabahah, ijarah, musyarakah, ar-rahn dan qardhul Hassan. Namun ada juga jenis produk simpanan yaitu simpanan amanah, simpanan wadiah, simpanan pendidikan, simpanan walimah, simpanan Idul Fitri, simpanan kurban dan simpanan haji.
Tapi dari beberapa produk yang ditawarkan oleh Baitul Maal Wa Tamwil produk mudharabah sering sekali diminati. Mudharabah adalah bentuk kerja sama antara dua belah pihak dimana pemilik modal (shohibul maal) mempercayakan sejumlah modal kepada pengelola (mudhorib) dengan perjanjian di awal. Bentuk ini menegaskan bahwa modal seratus persen dari pemilik modal dan keahlian dari pengelola. Dalam segi kuasa yang diberikan kepada pengelola, mudharabah terbagi dua jenis yaitu mudharabah muthlaqoh (investasi tidak terikat) dan mudharabah muqaidah (investasi terikat).

Mudharabah muthlaqoh yaitu pihak pengelola diberikan kuasa penuh untuk menjalankan proyek tanpa larangan/gangguan apapun urusan yang berkaitan dengan proyek itu dan tidak terikat dengan waktu, tempat, perusahaan dan pelanggan. Akan tetapi berbeda dengan mudharabah muqaidah yaitu pemilik dana/modal membatasi/memberi syarat kepada pengelola dana seperti misalnya hanya melakukan mudharabah dalam bidang tertentu, cara, waktu dan tempat tertentu.

Lembaga keuangan lain juga mempunyai produk yang menjadi daya saing untuk menarik minat calon anggota atau nasabah. Dengan kemajuan teknologi yang semakin canggih, banyak lembaga keuangan yang menggunakan teknologi untuk memasarkan produknya secara lebih luas. Hal ini menjadi daya tambah saing yang cukup sulit bagi Baitul Maal Wa Tamwil yang notabennya masih berkembang dan butuh daya sokong untuk mengembangkannya.

Untuk mengembangkannya dibutuhkan strategi yang tepat dan akurat, sehingga dalam 
persaingan yang ketat ini bisa tetap bertahan dan eksis di kalangan masyarakat. Strategi pemasaran mempunyai peran yang sangat penting untuk keberhasilan usaha perusahaan umumnya dan bidang pemasaran khususnya. Strategi pemasaran harus dapat memberi gambaran yang jelas dan terarah tentang apa yang akan dilakukan oleh perusahaan dalam menggunakan setiap kesempatan atau peluang pada beberapa pasar sasaran.

Supriyanto menyatakan bahwa strategi adalah suatu kesatuan rencana yang komprehensif dan terpadu yang menghumbungkan antara kekuatan strategi perusahaan dengan lingkungan yang dihadapi kesemuanya menjamin agar tujuan perusahaan tercapai (Supriyanto, 1991). Secara sederhana startegi diartikan suatu rencana yang diutamakan untuk mencapai tujuan (Bashu, 2000). Untuk mencapai tujuan tersebut secara maksimal, setiap perusahaan harus mengatur strategi sedemikian rupa seperti penempatan gedung, pemasaran produk, hingga kepada penjualan dan seterusnya.

Pemasaran merupakan suatu kegiatan yang sangat penting bagi perusahaan dalam rangka menyalurkan produk-produknya kepada masyarakat atau konsumen. Pemasaran di definisikan sebagai suatu proses sosial yang di dalamnya individu dan kelompok mendapatkan apa yang mereka inginkan dengan menciptakan, menawarakan dan secara bebas mentukarkan produk yang bernilai dengan pihak lain (Kottler, 1991). Dalam arti lain pemasaran berarti suatu sistem dengan keseluruhan dari kegiatan bisnis yang diajukan untuk merencankan, menentukan harga, mempromosikan dan mendistribusikan barang dan jasa yang memuaskan kebutuhan yang ada maupun pembeli yang potensial (Sumarni \& Suprihanto, 1998). Pemasaran juga dapat diartikan sebagai upaya untuk menciptakan dan menjual produk kepada berbagai pihak dengan maksud tertentu (Kasmir \& Jakfar, 2007). Sedangkan strategi pemasaran bisa didefinisikan sebagai suatu kegiatan menyeleksi dan penjelasan atau beberapa target pasar dan mengembangkan serta memelihara suatu bauran pemasaran yang akan menghasilkan kepuasan bersama dengan pasar yang dituju (Daniel, 2001).

Dalam strategi pemasaran biasanya mengacu pada faktor operasional atau pelaksanaan kegiatan pemasaran seperti penentuan harga, pemberian merek, pembungkusan, penentuan saluran distribusi, pemasangan iklan dan sebagainya. Kegiatan strategi pemasaran itu terdiri dari marketing mix yang meliputi product, price, place dan promotion. Hal ini strategi pemasaran mencakup serangkaian kegiatan analisis, perencanaan, pelaksanaan dan pengawasan atas barang dan jasa dan gagasan dengan tujuan utama kepuasan pihat yang terkait (Wahjono, 2010).

Penggunaan konsep pemasaran mempunyai tujuan utama untuk memperoleh keuntungan tertentu dan mengubah orientasi filsafah manajemen pemasaran lain yang ternyata telah terbukti berhasil mengatasi persoalan, karena adanya perubahan dalam pasar yang cenderung berkembang. Perubahan tersebut terjadi antara lain karena bertambahnya jumlah penduduk, bertambahnya daya beli, meningkat dan meluasnya hubungan atau komunikasi, berkembangnya teknologi, dan perubahan faktor lingkungan lainnya (Assauri, 2015). 
Tidak dapat dipungkiri bahwa keadaan suatu lembaga keuangan sekarang bersifat dinamis, yang selalu mengalami perubahan setiap saat dan adanya keterkaitan antara satu dengan yang lain. Oleh karena itu strategi pemasaran yang diterapkan harus ditinjau dan dikembangkan sesuai dengan perkembangan pasar dan lingkungan pasar tersebut. Dengan demikian strategi pemasaran harus dapat memberikan gambaran yang jelas dan terarah tentang apa yang dilakukan lembaga keuangan dalam menggunakan setiap kesempatan atau paduan pada beberapa pasar.

Tempat yang akan dijadikan penelitian adalah BMT Mitra Ummat Al-Amanah yang berda di Desa Sridadi kecamatan Sirampog kabupaten Brebes. BMT Mitra Ummat Al-Amanah merupakan lembaga keuangan yang menghimpun dan menyalurkan dana dari masyarakat yang memiliki ekonomi lebih ke masyarakat yang lebih membutuhkan. BMT Mitra ummat Al-Amanah ini mempunyai keunggulan dibandingkan lembaga keuangan lainnya yang ada di Kecamatan Sirampog diantaranya menyalurkan Kredit Perumahan Rakyat Bersubsidi (KPRS) kepada warga masyarakat melalui kerjasama dengan Kementrian Perumahan Rakyat (MENPERA), menyediakan pembayaran listrik secara online, menyisihkan $20 \%$ dari sisa usaha (keuntungan) untuk biaya pendidikan dan sosial, dan memberikan pinjaman tanpa bagi hasil kepada warga yang terkena musibah (sakit) untuk berobat.

Kecamatan Sirampog merupakan sebuah kecamatan yang terletak di ujung tenggara kabupaten Brebes dan berbatasan langsung dengan kabupaten Tegal. Pusat pemerintahan kecamatan sirampog sendiri berada di desa Buniwah.
Kecamatan Sirampog ini memiliki luas 67 (enam puluh tujuh) $\mathrm{km}^{2}$ dengan jumlah penduduk sekitar 88.292 (delapan puluh delapan ribu dua ratus sembilah puluh dua) jiwa yang tersebar di 13 (tiga belas) desa. Secara geografis Kecamatan Sirampog yang berada paling barat merupakan dataran rendah dan sebagaian besar mempunyai karakter pekerjaan penduduk sebagai petani padi, guru dan karyawan. Sedangkan yang berada di dataran tinggi mempunyai karater pekerjaan mayoritas sebagai petani sayur-sayuran, bahkan menjadi pemasok sayur-sayuran untuk kecamatan Bumiayu, Ajibarang dan Cirebon.

Alasan peneliti memilih BMT Mitra Ummat Al-Amanah karena ingin mengetahui startegi pemasaran produk mudharabah yang digunakan. Dimana startegi pemasaran tersebut dapat mempertahankan dan mengkokohkan sehingga dapat bertahan di era persaingan teknologi ini. Kemudian berbagai informasi dari BMT Mitra Ummat Al-Amanah Kecamatan Sirampog akan menjadi bahan penelitian dan pembahasan dalam penelitian yang akan dilakukan.

\section{METODE}

Untuk mendapatkan hasil yang sempurna dan memuaskan dalam penelitian, maka perlu digunakan metodologi yang mendukung kesempurnaan penelitian ini.

\section{Jenis Penelitian}

Jenis penelitian ini adalah penelitian deskriptif-kualitatif yaitu jenis penelitian yang menggambarkan keadaan objek atau peristiwa yang terjadi saat penelitian berjalan dan penyuguhan apa adanya. Dalam penelitian ini dimaksudkan untuk mengetahui strategi pemasaran 
produk mudharabah yang digunakan BMT Mitra Ummat Al-Amanah Kecamatan Sirampog Brebes.

\section{Subjek dan Objek Penelitian}

Subjek penelitian adalah pihak-pihak yang dijadikan sebagai sampel dalam sebuah penelitian. Subjek penelitian juga membahas karakteristik subjek yang digunakan dalam penelitian, termasuk penjelasan mengenai populasi, sampel dan teknik sampling yang digunakan. Adapun subjek penelitian ini yaitu Direktur BMT Mitra Ummat Al-Amanah. Objek penelitian adalah variabel atau apa yang menjadi titik perhatian suatu penelitian, sedangkan subjek penelitian merupakan tempat dimana variabel melekat. Adapun yang menjadi objek penelitian ini yaitu BMT Mitra Ummat AlAmanah Kecamatan Sirampog.

\section{Sumber dan Jenis Data}

Sumber data dalam penelitian yaitu subjek darimana data diperoleh. Dalam penelitian ini penulis menggunakan dua sumber data sebagai berikut:

a. Data primer adalah data yang diperoleh dari sumber utama. Dalam penelitian ini data primer berupa hasil dari wawancara dengan Bapak Sabar selaku Direktur BMT Mitra Ummat AlAmanah Kecamatan Sirampog.

b. Data sekunder adalah data yang diperoleh dari literatur-literatur atau bacaan yang relevan berhubungan dengan masalah penelitian ini seperti brosur dan company profile.

\section{Teknik Pengumpulan Data}

Dalam penelitian ini metode yang digunakan dalam pengumpulan data yaitu:

a. Metode wawancara adalah suatu percakapan yang diarahkan pada suatu masalah tertentu. Ini merupkan proses tanya jawab lisan, dimana dua orang atau lebih saling berhadapan secara fisik. Komunikasi yang dilakukan secara langsung berguna untuk mendapatkan keterangan atau data yang berhubungan dengan masalah yang diteliti (Sarwono, 2010). Sebagai objek wawancara yaitu Direktur pada BMT Mitra Ummat Al-Amanah.

b. Metode dokumentasi adalah pengambilan data yang diperoleh dari dokumen atau sekumpulan berkas. Dokumen tersebut berupa berupa catatan, transkrip, buku, surat kabar, majalah, notulen, dan sebagainya yang ada di BMT Mitra Ummat Al- Amanah.

c. Metode observasi adalah pengamatan dan pencatatan secara langsung yang sistematis terhadap gejala-gejala yang diteliti. Teknik observasi ini akan dilakukan untuk mengamati bagaimana startegi pemasaran produk mudharabah di BMT Mitra Ummat Al-Amanah Kecamatan Sirampog.

\section{Teknik Analisis Data}

Teknik analisa data adalah proses pencarian dan penyusunan data yang sistematis melalui transkrip wawancara dan catatan lapangan, serta dokumentasi yang secara akumulasi menambah pemahaman peneliti terhadap yang ditemukan. Dalam menganalisa data penulis menggunakan metode bersifat deskriftif kualitatif yaitu menganalisa data dengan jalan mengklasifikasi data-data berdasarkan kategori-kategori atas dasar persamaan jenis data tersebut, kemudian diuraikan sehingga diperoleh gambaran yang utuh tentang masalah yang diteliti.

\section{HASIL DAN PEMBAHASAN}

Cara Memasarkan Produk Mudharabah 
Strategi pemasaran pada dasarnya adalah rencana yang menyeluruh, terpadu dan menyatu dibidang pemasaran yang memberikan panduan tentang kegiatan yang akan dijalankan untuk dapat tercapainya tujuannya pemasaran suatu perusahaan. Strategi pemasaran diperlukan pada sebuah lembaga keuangan syariah mikro seperti BMT Mitra Ummat Al-Amanah Sirampog Brebes, dimana lembaga ini selain berorientasi pada fungsi profit, lembaga ini juga mempunyai kapasitas sebagai lembaga yang berorientasi pada fungsi sosial.

Dalam memasarkan produk mudharabah kepada para anggota atau nasabahnya, BMT Mitra Ummat Al-Amanah Sirampog Brebes melakukan berbagai cara diantaranya mendatangi pengajian atau majelis Muhammadiyah rutin bulanan yang ada di Kecamatan Sirampog dan sekitarnya, promosi dengan menggunakan media seperti kalender dan mendatangi para petani sayur.

Dengan memberikan penjelasan dan manfaat mengenai produk mudharabah pada saat ada pengajian ranting Muhammadiyah sehingga nasabah dalam hal ini saling menginformasikan dari nasabah satu ke nasabah lain. Kemudian BMT Mitra Ummat Al-Amanah Sirampog Brebes juga memberikan penjelasan mengenai persyaratan yang harus dipenuhi oleh anggota atau calon anggota yang akan membuka rekening.

Tidak hanya mendatangi pengajian rutin Muhammadiyah saja, akan tetapi BMT Mitra Ummat Al-Amanah Sirampog Brebes juga mengunakan promosi dengan media sebuah kalender yang dapat dilihat ketika anggota atau calon anggota melihat tanggal dan hari di kalender. Disisi lain juga BMT Mitra Ummat Al-Amanah
Sirampog Brebes mendatangi petani-petani sayur yang sedang diladang dekat jalan raya untuk mensosialisasikan produk mudharabah yang memiliki banyak manfaat.

Selama dalam perkembangannya produk mudharabah sangat diminati oleh anggota atau calon anggota. Hingga sampai saat ini BMT Mitra Ummat Al-Amanah membatasi jumlah anggota untuk produk pembiayaan mudharabah hanya 200 (dua ratus) yang diterima, tapi berbeda dengan calon anggota yang mendaftar melebihi dari perkiraan yaitu sejumlah 500 (lima ratus) orang lebih yang mendaftarkan diri sebagai calon anggota.

Pada pelaksanaan pelayanan kepada anggota dan calon anggota BMT Mitra Ummat Al-Amanah memberikan kemudahan dan cara untuk memanfaatkan jasa BMT, baik pengajuan usulan pembiayaan usaha dilakukan dengan sistem yang sederhana serta tidak berbeli-belit. Jadi prosedur yang diterapkan pada BMT Mitra Ummat AlAmanah Sirampog mempunyai aturan atau mekanisme yang sederhanan. Namun dengan demikian pengelola tetap berhati-hati untuk melakukan pembiayaan terhadap usaha yang diusulkan. Hal ini untuk menghindari kerugian serta menjaga agar usaha tersebut benar-benar kredibel. Adapun prosedur pelayanan BMT Mitra Ummat Al-Amanah Sirampog kepada anggota atau calon anggota mengenai hal pinjaman atau pembiayaan sesuai dengan prinsip hukum syariah sebagai berikut:

1. Telah menjadi anggota atau calon anggota secara aktif selama 3 bulan.

2. Mempunyai simpanan paling sedikit $\mathrm{Rp}$ $600.000,00$. 
3. Datang langsung ke BMT Mitra Ummat AlAmanah Sirampog.

4. Memperlihatkan buku simpananya.

5. Mengisi formulir yang telah disediakan dengan melampirkan foto copy KTP 2 lembar.

6. Menandatangani akad perjanjian pinjaman dengan ketentuan:

a. Ditandatangai oleh peminjam dan bagian pembiayaan.

b. Dalam akad terjadi kesepakatan antara peminjam dengan pihak BMT Mitra Ummat Al-Amanah Sirampog dimana peminjam akan memberikan bagi hasil kepada BMT sesuai dengan kesepakatan yang telah dibuat bersama.

7. Menyerahkan barang jaminan baik barang bergerak maupun tidak bergerak.

8. Menyerahkan surat tanda bukti hak atas barang baik bergerak maupun tidak bergerak yang dijaminkan.

9. Memberikan surat kuasa menjual kepada BMT Mitra Ummat Al-Amanah Sirampog bila mana peminjam tidak dapat melunasi.

Dari paparan di atas menurut penulis pemasaran dilakukan dengan cara memberikan penjelasan dan manfaat mengenai produk pembiayaan mudharabah pada saat pengajian ranting Muhammadiyah sudah cukup bagus, akan tetapi perlu ditingkatkannya lagi dengan cara mengadakan seminar tersendiri yang dilakukan oleh team pemasaran BMT Mitra Ummat AlAmanah Sirampog. Supaya masyarakat lebih paham mengenai produk mudharabah khususnya dan prodak lain yang ada di BMT secara umumnya.

\section{Strategi Pemasaran Produk Mudharabah}

Aktivitas pemasaran diperlukan baik oleh perusahaan yang baru diluncurkan maupun perusahaan yang sudah lama berjalan. Pemasaran merupakan salah satu faktor penentu keberhasilan suatu perusahaan, oleh sebab itu pemasaran selalu memperoleh posisi paling penting dan dipandang sebagai jantung sebuah perusahaan. Tanpa adanya pemasaran, suatu perusahaan akan seperti kehilangan dorongan untuk bertahan dan bersaing dalam persaingan yang ketat kemudian selanjutnya membawa perusahaan menuju titik kemunduran atau kebangkrutan akibat kalah dalam persaingan pasar.

Pembahasan akan dimulai dengan BMT Mitra Ummat Al-Amanah Sirampog melakukan segmentasi pasar, penentuan target pasar dan positioning. Segmetasi pasar yang dilakukan BMT Mitra Ummat Al-Amanah Sirampog merupakan langkah pertama yang mempelajari bagaimana BMT Mitra Ummat Al-Amanah Sirampog akan bersaing dalam pemasaran dan kemudian menentukan konsumen yang akan menjadi sasaran produk pembiayaan mudharabah.

1. Segmentasi Demografi

Pada segmentasi demografi variabel yang sering digunakan adalah jenis kelamin, pendapatan, pekerjaan, pendidikan, usia, agama, kebangsaan, kelas sosial dan daur hidup keluarga.

Penulis melihat Segementasi demografi yang dilakukan oleh BMT Mitra Ummat AlAmanah Sirampog terhadap produk mudharabah seperti yang dijleaskan di atas adalah adanya batasan terhadap umur dan pendidikan. Jika masih dibawah umur atau 
masih dalam jenjang pendidikan belum diperbolehkan untuk mengajukan pembiayaan produk mudharabah dikarenakan belum mempunyai pendapatan sendiri. Akan tetapi tidak ada batasan dari segi jenis kelamin, pendapatan, pekerjaan, agama, kebangsaan, kelas sosial dan daur hidup keluarga, mereka berhak menikmati produk mudharabah yang diterapkan oleh BMT Mitra Ummat AlAmanah Sirampog. Karena produk mudharabah merupakan produk pembiayaan yang mengandung nilai-nilai luhur kemanusiaan dan perwujudan prinsip keadilan dalam sebuah usaha ekonomi. Produk mudharabah dari BMT Mitra Ummat Al-Amanah Sirampog memberikan kesempatan kepada anggota atau calon anggota untuk mengembangkan usahanya dengan dibantu modal untuk bisa lebih melebarkan usahanya agar lebih maju lagi.

2. Segmentasi Geografi

Segmentasi geografi misalnya dengan menggunakan variabel seperti propinsi, kabupaten, kecamatan dan desa.

Segmentasi geografi BMT Mitra Ummat Al-Amanah Sirampog terhadap produk mudharabah berdasarakan propinsi adalah propinsi Jawa Tengah dan sekitarnya. Berdasarkan kabupaten adalah Brebes dan sekitarnya. Berdasarakan kecamatan adalah kecamatan Sirampog, Bumiayu, Tonjong, Paguyangan, Bantakawung dan sekitarnnya. Berdasarakan Desa adalah Desa Sridadi, Kaligiri, Mendala, Dawuhan, Igirklanceng, Buniwah, Plompong dan sekitarnya yang berada dekat dengan Sridadi dimana kantor
BMT Mitra Ummat Al-Amanah Sirampog berada.

Dalam segmentasi ini penulis melihat bahwa cakupan BMT Mitra Ummat AlAmanah Sirampog terhadap produk mudharabah bukan hanya di desa saja yang ada di kecamatan sirampog, tetapi sudah meranah sampai ke wilayah pinggiran Tegal yang dekat dengan kecamatan Sirampog dan ini sebuah langkah yang baik untuk diteruskan dalam proses pemasaran.

Setelah proses segmentasi diselesaikan maka langkah selanjutnya adalah penentuan target pasar. Langkah ini pada dasarnya adalah mengevaluasi daya tarik setiap segmen dan memeriksa apakah segmen tersebut sesuai dengan kapabilitas dan sumber daya yang dimiliki oleh BMT Mitra Ummat Al-Amanah Sirampog.

Target pasar yang dilakukan oleh BMT Mitra Ummat Al-Amanah Sirampog terhadap produk mudharabah adalah semua market dimasuki baik dari segi demografi dan geografi, khususnya kepada anggota atau calon anggota yang mempunyai usaha rill yang dapat berkembang lebih luas lagi dan yang bertempat tinggal di desa Sridadi kecamatan Sirampog dan sekitarnya. Karena produk mudharabah hadir di tengah-tengah masyarakat dalam rangka membantu dan meningkatkan perekonomian masyarakat baik kelas menengah maupun kebawah supaya perekonomian menjadi lebih baik lagi dimasa sekarang dan masa depan.

Setelah memilih target pasar, maka langkah BMT Mitra Ummat Al-Amanah 
Sirampog selanjutnya menetapkan posisi dirinya sedemikian relatif terhadap pesaingnya. Artinya BMT Mitra Ummat Al-Amanah Sirampog harus memiliki dan memperlihatkan keunggulannya dibanding lembaga keuangan lainnya.

Produk mudharabah yang di terapakan oleh BMT Mitra Ummat Al-Amanah Sirampog jelas akan menjadi menarik masyarakat untuk menjadi anggotanya, karena produk mudharabah memiliki keunggulan:

1. Produk mudharabah merubakan sebuah produk yang ada di BMT Mitra Ummat AlAmanah Sirampog yang notabene sudah mempunyai umur dan sebagian besar masyarakat sudah mengetahui keberadaanya.

2. Produk mudharabah memberikan kemudahan bagi anggota dalam melakukan pengajuan pembiayaan untuk mengembangkan usahanya yang kekurangan modal usaha.

3. Produk mudharabah sangat efektif, karena setiap anggota yang mengajukan pembiayaan dapat meningkatan atau mengembangkan usahanya dan mendapatkan lebih banyak keuntungan.

4. Jika melihat kondisi sekarang, kebutuhan yang semakin meningkat menyebabkan para pengusaha meningkatkan jumlah usahanya. Sehingga perencanaan usaha yang dibuat dapat lebih berkembang dengan sokongan modal dari produk mudharabah.

5. Meningkatnya harga dalam perekonomian biasanya para pengusaha mengambil modal usahanya untuk memenuhi menutup kebutuhan yang membengkak. Dengan adanya produk mudharabah sangatlah diperlukan untuk menambah modal pengusaha.

Untuk mencapai pasar sasaran tersebut strategi pemasaran produk mudharabah yang dilakukan oleh BMT Mitra Ummat Al-Amanah Sirampog meliputi beberapa variabel dalam strategi pemasaran yaitu:

1. Strategi Produk

Dari keseluruhan bauran pemasaran, startegi produk adalah startegi yang paling krusial. Beberapa strategi pemasaran lainnya berkaitan dengan produk yang dihasilkan. Dengan demikian startegi lainnya belum relevan apabila produknya belum eksis. Dalam konteks pemasaran produk mencakup produk fisik, jasa, pengalaman, ide, properti dan lain-lain.

Startegi produk yang dilakukan oleh BMT Mitra Ummat Al-Amanah Sirampog dalam upaya menarik minat anggota adalah dengan menampilkan kualitas yang baik dari produk mudharabah tersebut, sehingga dapat memenuhi keinginan atau kebutuhan pasar sasarannya. Kualitas dari produk mudharabah ini meliputi pemberian fasilitas dan kemudahan dalam peryaratan yang terdapat didalam karakteristik produk antara lain:

a. Dengan adanya produk mudharabah kekurangan modal dapat teratasi dengan baik bebas dari bunga.

b. Dapat memperluas usaha melalui penambahan modal. 
c. Mudharabah merupakan produk bagi hasil yang $100 \%$ modal dari BMT.

d. Bagi hasil diberikan sesuai perjanjian diawal.

e. Dalam hal mengangsur mendapatkan fasilitas dijemput ditempat, dengan kata lain petugas bisa mendatangi rumahrumah anggota yang akan melakukan pembayaran angsuran.

f. Persyaratan menjadi anggota sangat mudah dan murah.

Dengan strategi produk yang dilakukan oleh BMT Mitra Ummat AlAmanah Sirampog terhadap produk mudharabah diharapkan dapat menarik minat masyarakat untuk menjadi anggota.

2. Strategi Harga

Harga merupakan sejumlah uang yang harus disetorkan anggota untuk memperoleh sebuah produk. Harga juga salah satu elemen strategi pemasaran yang perlu mendapat perhatian, paling tidak ada beberapa alasan mengapa harga layak memperoleh perhatian:

a. Harga merupakan salah satu komponen yang dapat digunakan oleh entrepreneur untuk meningkatan reveneu perusahaan selain dengan meningkatkan volume produk yang dijual.

b. Harga merupakan elemen bauran pemasaran yang paling mudah dirubah. Mengubah produk, promosi atau disribusi mungkin memerlukan waktu beberapa bulan sedangkan mengubah harga dapat dilakukan pada saat ini juga.

c. Strategi dan taktik harga pesaing memberikan pengaruh besar terhadap penjualan suatu perusahaan.

d. Harga merupakan salah satu komponen yang digunakan untuk diferensiasi pada pasar yang telah jenuh dan terjadi komoditasi produk.

Harga harus ditentukan besarnya, hal ini sangat penting karena harga dapat menentukan laku tidaknya produk yang ditawarkan di pasar. Salah menentukan harga akan berakibat fatal bagi produk yang ditawarkan.

Penetapan staretgi harga pada produk mudharabah yang dilakukan oleh BMT Mitra Ummat Al-Amanah Sirampog adalah berupa sistem bagi hasil dan biaya yang dikeluarkan oleh mitra. Sistem bagi hasil merupakan suatu sistem yang meliputi tatacara bagi hasil usaha antara penyedia dana dan pengelola dana atau BMT Mitra Ummat Al-Amanah Sirampog dengan anggota yang mengajukan dana. Selain sistem bagi hasil, penetapan startegi harga yang dilakukan oleh BMT Mitra Ummat AlAmanah Sirampog pada produk mudharabah adalah dengan memberikan persyaratan berupa dana simpanan minimal Rp 600.000,-.

3. Strategi Promosi

Dalam aktivitas yang menunjang keberhasilan staretgi pemasaran lainnya. Tanpa promosi keunggulan produk tidak dapat diketahui oleh konsumen. Program 
harga diskon yang disusun perlu diperkuat dengan iklan sehingga diketahui oleh target pasar. Komponen promosi terdiri dari periklanan, hubungan masyarakat, penjualan personal dan promosi penjualan. Adapun promosi yang dilakukan oleh BMT Mitra Ummat Al-Amanah Sirampog pada produk mudharabah untuk menunjang keberhsilan dalam promosi yang dilakukan adalah sebagai berikut:

a. Melalui personal selling

Promosi ini dilakukan oleh karyawan khususnya marketing BMT Mitra Ummat Al-Amanah Sirampog dalam melayani serta ikut memengaruhi anggota atau calon anggota, mensosialisasikan dan menawarkan produk mudharabah kepada anggota potensial secara langsung.

b. Melalui periklanan

Promosi dilakukan dalam bentuk tayangan atau gambar atau bahkan katakata yang tertuang dalam spanduk, brosur, kalender dan lain-lain. Dalam hal ini BMT Mitra Ummat Al-Amanah Sirampog hanya menggunakan media cetak dengan pembuatan sebuah kalender dan disebar ke masyarakat Kecamatan Sirampog.

c. Melalui publisitas

Promosi yang dilakukan untuk meningkatkan citra perusahaan di depan para anggota atau calon anggota melalui kegiatan pengajian, yaitu BMT Mitra Ummat Al-Amanah Sirampog mendatangi pengajian cabang atau ranting Muhammadiyah di kecamatan Sirampog dan sekitarnya. Selain itu BMT Mitra Ummat Al-Amanah Sirampog juga membayar honor kepada pengajar di salah satu lembaga pendidikan di wilayah Dawuhan yaitu madrasah diniyah.

Dengan adanya promosi-promosi yang dilakukan oleh BMT Mitra Ummat Al-Amanah Sirampog yang sudah baik ini, akan tetapi promosi periklanan diharapkan dapat dikembangkan lagi bukan hanya dengan kalender saja, supaya dapat menarik minat masyarakat untuk segera bergabung di BMT Mitra Ummat Al-Amanah Sirampog dengan menjadi anggota dan membuka rekening produk-produknya, khususnya produk mudharabah. Agar masyarakat dapat menikmati fasilitas-fasilitas pelayanan yang diberikan oleh BMT Mitra Ummat Al-Amanah.

\section{SIMPULAN}

Berdasarakan penelitian yang dilakukan oleh penulis, maka penulis dapat menyimpulkan sebagai berikut:

1. Cara memasarkan produk mudharabah BMT Mitra Ummat Al-Amanah Sirampog Brebes yaitu dengan memberikan informasi dan manfaat produk mudharabah saat dipengajian rutinitas yang diadakan oleh Ranting Muhammadiyah di Kecamatan Sirampog.

2. Dalam startegi pemasaran yang dilakukan oleh BMT Mitra Ummat Al-Amanah Sirampog Brebes dalam segmentasi demografi tidak tebatas oleh pendidikan, kelamin, agama, kelas sosial, pendapatan. Siapapun boleh untuk 
mengajukan pembiayaan produk mudharabah dengan catatan untuk mengembangkan usaha yang dijalaninya.

3. Dalam segmen geografi BMT Mitra Ummat Al-Amanah Sirampog Brebes untuk startegi produk mudharabah mencakup wilayah wilayah yang berada disekitar Desa Sriadadi yang meliputi Kaligiri, Dawuhan, Igirklanceng, Mendala, Plompong, Buniwah dan daerah pinggiran Kabupaten Tegal yang dekat dengan Kecamatan Sirampog.

4. Dengan menggunakan strategi produk BMT Mitra Ummat Al-Amanah Sirampog Brebes menampilkan produk mudharabah yang kualitasnya tidak diragukan lagi, dari mudahnya persyaratan sampai pada saat mengangsur mendapatkan fasilitas dijemput ditempat.

5. Dengan strategi harga yang ditawarkan oleh BMT Mitra Ummat Al-Amanah Sirampog Brebes dengan sejumlah Rp 600.000,- sebagai syarat utama uang yang ada ditabungan selama 3 (tiga) bulan merupakan sebuah harga yang mudah dijangkau untuk berbagai kalangan.

6. Promosi merupakan salah satu strategi yang digunakan oleh BMT Mitra Ummat AlAmanah Sirampog Brebes diantaranya yaitu personal selling, periklanan dan publisitas.

\section{DAFTAR PUSTAKA}

Amir, T. (2004). Dinamika Pemasaran. PT Raja Grasindo Persada.

Amrin, A. (2007). Strategi Pemasaran Asuransi Syariah. PT Grasindo.

Assauri, S. (2015). Manajemen Pemasaran (Dasar, Konsep, Strategi). PT Raja Grafindo Persada.
Azra, A. (2003). Berderma Untuk Semua. PT Mizan Pustaka.

Bashu, S. (2000). Strategi Pemasaran Dalam Bisnis. Gramedia Pustaka.

Daniel, M. (2001). Pemasaran. Salemba Empat.

Janwari, Y., \& Djazuli. (2002). Lembaga-Lembaga Perekonomian Umat (Suatu Pengenalan). PT Raja Grafindo Persada.

Kartajaya, H., \& Sula, M. S. (2006). Syariah Marketing. PT Mizan Pustaka.

Kasmir, \& Jakfar. (2007). Studi Klayakan Bisnis (II). Kencana.

Kotler, P., \& Armstrong, G. (2001). PrinsipPrinsip Pemasaran (R. A. Rusli (ed.)). Erlangga.

Kottler, P. (1991). Dasar-Dasar Pemasaran (Benyamin Molan (ed.)). PT Prehallindo.

Rangkuti, F. (2006). Analisis SWOT Teknik Membedah Kasus Bisnis (Reorientasi Konsep Perencanaan Srategis Untuk Menghadapi Abad 21). PT Gramedia Pustaka Utama.

Rangkuti, F. (2009). Strategi Promosi yang Kreatif dan Analisis Kasus (Integrated Marketing Communication). PT Gramedia Pustaka Utama.

Sarwono, J. (2010). Pintar Menulis Karya Ilmiah (Kunci Sukses Dalam Menulis Ilmiah). Andi Offset.

Sumarni, M., \& Suprihanto, J. (1998). Pengantar Bisnis ( Dasar-Dasar Ekonomi Perusahan) (V). Liberty.

Sumiyanto, A. (2008). Menuju Koperasi Modern (Panduan Untuk Pemilik, Pengelola dan Pemerhati Baitul Maal Wa Tamwil dalam Format Koperasi). Debeta.

Supriyanto. (1991). Manajemen Strategi dan Kebijakan Bisnis. BPFE.

Tohar, M. (2000). Membuka Usaha Kecil. Kanisius.

Umar, H. (2008). Strategic Management in Action. PT Gramedia Pustaka Utama.

Wahjono, S. I. (2010). Manajemen Pemasaran 
406 Strategi Pemasaran Produk Mudharabah di BMT Mitra Ummat Al-Amanah Kecamatan Sirampog, Brebes - Muhamad Syafiq Rofi

DOI : https://doi.org/10.31004/abdidas.v1i5.91

Bank. Graha Ilmu.

Wiroso. (2005). Penghimpunan Dana dan Distribusi Hasil Usaha Bank Syariah. PT Grasindo. 